COLLECTIVE ACTION AND EXCHANGE 



\title{
COLLECTIVE ACTION
}

\section{AND EXCHANGE}

\author{
A Game-Theoretic Approach to \\ Contemporary Political Economy
}

WILLIAM D. FERGUSON

STANFORD ECONOMICS AND FINANCE

An Imprint of Stanford University Press

Stanford, California 
STANFORD UNIVERSITY PRESS

Stanford, California

(C) 2013 by the Board of Trustees of the Leland Stanford Junior University. All rights reserved.

No part of this book may be reproduced or transmitted in any form or by any means, electronic or mechanical, including photocopying and recording, or in any information storage or retrieval system without the prior written permission of Stanford University Press.

Special discounts for bulk quantities of titles in the Stanford Economics and Finance imprint are available to corporations, professional associations, and other organizations. For details and discount information, contact the special sales department of Stanford University Press. Tel: (650) 736-1782, Fax: (650) 736-1784.

Printed in the United States of America on acid-free, archival-quality paper

Library of Congress Cataloging-in-Publication Data

Ferguson, William D., 1953 - author.

Collective action and exchange : a game-theoretic approach to contemporary political economy / William D. Ferguson.

pages $\mathrm{cm}$

Includes bibliographical references and index.

ISBN 978-0-8047-7003-3 (cloth : alk. paper)-ISBN 978-0-8047-7004-0 (pbk. : alk. paper)

1. Game theory. 2. Economics-Mathematical models. I. Title.

HB144.F467 2013

$330.01^{\prime} 5193$ - dc23

ISBN 978-0-8047-8556-3 (electronic)

Typeset by Newgen in 10/14 Minion 
Dedicated to the memory of Elinor (Lin) Ostrom, political scientist, and my father Allen R. Ferguson, economist. 

What is missing from the policy analyst's tool kit — and from the set of accepted, well-developed theories of human organization - is an adequately specified theory of collective action whereby a group of principals can organize themselves voluntarily to retain the residuals of their own efforts.

Elinor Ostrom 
